\title{
ASOSIASI FUNGI MIKORIZA ARBUSKULA (FMA) DENGAN TANAMAN JELUTUNG (Dyera spp.) PADA TANAH BERPASIR DI PASIR PANJANG KOTA SINGKAWANG
}

\author{
(Association of Arbuskula Mikoriza (FMA) Fungi With Jelutung (Dyera spp.) Plant On Sanded \\ Land In The Pasir Panjang Of Singkawang City)
}

\author{
Desti, Abdurrani Muin, dan Rosa Suryantini \\ Fakultas Kehutanan Universitas Tanjungpura Jalan Imam Bonjol Pontianak 78124 \\ Email: destiagdes@gmail.com
}

\begin{abstract}
In order to preserve jelutung plants, the Regional Government of Singkawang City has planted 38 trees in the Pasir Panjang area of Singkawang City. The purpose of this study: (1) to study the association of jelutung plants (Dyera spp) on those planted in Pasir Panjang Singkawang, (2) to determine the number of spores and their correlation with tree diameter, (3) to determine the FMA genus contained in the rhizosphere, and (4) percentage of root colonization to determine the level of association of AMF with jelutung plants. The study was conducted by survey method for sampling soil and roots of jelutung plants. Data were collected and analyzed in the form of the average number of spores, genus AMF and the percentage of infections in the roots of jelutung plants. The results of the research that has been done can be concluded that jelutung plants (Dyera spp) that grow in sandy habitats in the Pasir Panjang area of Singkawang City are associated with arbuscular mycorrhizal fungi (FMA). The results of spore calculations found in jelutung rhizosphere in sandy soil habitats are quite abundant with amounts ranging from 436 - 1279,67/100g of soil. The results of correlation analysis with the coefficient of determination $r 2=0,0169$ showed no close relationship between diameter size and the number of spores in the jelutung rhizosphere of sandy soils. From the results of spore calculations, the genus Glomus sp found in the jelutung (Dyera spp) rhizosphere was 874,33 / $100 \mathrm{~g}$ of soil (96,8\%), while the genus Gigaspora sp was only 23,97/ $100 \mathrm{~g}$ of land (2,6\%), and Scutellospora sp only 5,50 / $100 \mathrm{~g}$ of soil (0,6\%). Based on the calculation of the percentage of infections that occur at the root, it turns out that jelutung plants are included as a high level association with the percentage of infections ranging from 8,7 - 100\% or being in grade 5.
\end{abstract}

Keywords: Arbuscular Mycorrhizal Fungi (AMF), Jelutung Plants, Number of Spores, Percentage of Root Infection.

\section{PENDAHULUAN}

Potensi jenis jelutung di hutan alam diduga semakin berkurang seiring berjalannya waktu. Potensi yang terus menurun ini disebabkan oleh penebangan pohon untuk dimanfaatkan kayunya dan rusak atau mati akibat praktek penyadapan getah yang tidak sesuai dengan aturan. Penyebab lain adalah karena permudaan alam jenis ini sangat jarang terjadi (Sitepu et al. 2010). Potensi yang terus berkurang, menyebabkan jenis ini sulit dijumpai di dalam kawasan hutan alam. Semantara itu upaya budidaya jelutung rentan 
mengalami kegagalan karena sering terjadi kebakaran, yang mengakibatkan menurunnya produksi getah jelutung dalam dua dekade terakhir dan menjadi ancaman terhadap kelestariannya (Sofiyuddin et al. 2012). Potensi di hutan alam dan menurunnya produksi menunjukkan bahwa kelestarian mulai terancam.

Dalam rangka melestarikan jenis tanaman jelutung, Pemerintah daerah Kota Singkawang telah melakukan penanaman sebanyak 38 pohon di daerah Pasir Panjang Kota Singkawang. Pohon-pohon tersebut ditanam pada tapak tanah berpasir yang bukan merupakan habitat aslinya. Selama ini sudah diketahui bahwa habitat tanaman jelutung adalah hutan rawa (swamp forest). Hasil pengamatan di lapangan, tanaman jelutung bisa tumbuh subur pada tanah berpasir dengan berbagai ukuran diameter. Salah satu yang menyebabkan tanaman tersebut tumbuh dengan subur, diduga tanaman jelutung tersebut berasosiasi dengan fungi mikoriza arbuskuka (FMA). Menurut Muin (2009) fungi mikoriza berfungsi dalam hal penyerapan unsur hara, meningkatkan ketahanan terhadap kekeringan, serangan patogen akar dan produksi hormon pertumbuhan serta menjamin terselenggaranya siklus hara termasuk fungi mikoriza arbuskula (Muin 2009). Menurut Nurhatika (2014) fungi mikoriza arbuskula merupakan salah satu mikroorganisme yang sangat membantu dalam siklus unsur hara dan memfasilitasi penyerapan hara dalam tanah sehingga dapat meningkatkan pertumbuhan tanaman.
Penelitian Turjaman. et al. 2007 telah menemukan bahwa jelutung (Dyera spp) pada habitat aslinya (hutan rawa) bersimbiosis dengan fungi mikoriza arbuskula. Meskipun sudah diketahui berasosiasi pada habitat aslinya, namun belum ada penelitian mengenai asosiasi FMA tanaman jelutung yang tumbuh atau ditanam di tapak berpasir. Jika tanaman jelutung tersebut bersimbiosis dengan fungi mikoriza, maka perlu diketahui bagaimana asosiasi antara jelutung dengan fungi mikoriza tersebut terutama dalam hal jumlah dan genus spora serta tingkat asosiasi dan genus FMA dengan tanaman jelutung tersebut. Apakah ukuran diameter pohon tersebut berkorelasi dengan jumlah spora yang terdapat pada rhizosfer tanaman jelutung. Untuk mengetahuinya, perlu suatu kajian mengenai asosiasi fungi mikoriza arbuskula (FMA) pada tanaman jelutung (Dyera spp) di Pasir Panjang kota Singkawang Kalimantan Barat.

Tujuan penelitian ini : (1) melakukan kajian asosiasi tanaman jelutung (Dyera spp) yang ditanam pada tapak berpasir di Pasir Panjang Singkawang, menentukan jumlah spora dan korelasinya dengan ukuran diameter pohon, (3) menentukan genus FMA yang terdapat pada rhizosfer, dan (4) persentase kolonisasi akar untuk menentukan tingkat asosiasi FMA dengan tanaman jelutung tersebut. Hasil penelitian ini diharapkan dapat dijadikan sebagai acuan untuk memanfaatkan fungi mikoriza arbuskula dalam rangka perluasan tanaman jelutung di luar habitatnya dan sebagai acuan untuk melakukan inokulasi pada tanaman jelutung. 


\section{METODE PENELITIAN}

Penelitian dilaksanakan di Pasir Panjang Kota Singkawang dan Laboratorium Silvikultur Fakultas Kehutanan Untan selama dua bulan. Pengambilan sampel tanah dan akar dilakukan di bawah tegakan tanaman jelutung (Dyera sp) di Pasir Panjang. Proses penyaringan, pengamatan dan identifikasi spora, serta pengamatan kolonisasi akar dilakukan di Laboratarium Silvikultur Fakultas Kehutanan Universitas Tanjungpura Pontianak.

Penelitian dilakukan dengan metode survei untuk pengambilan contoh tanah dan akar tanaman jelutung. Pengambilan sampel tanah dan akar dilakukan dengan teknik sampling secara acak metode (lotere) sebanyak 10 pohon (26\%) dari 38 tanaman jelutung yang ditanam di Pasir Panjang. Sampel akar dan tanah diambil pada 3 (tiga) titik di sekitar rhizosfer tanaman jelutung dengan kedalaman 10 $\mathrm{cm}$. Contoh tanah dan akar yang sudah diambil, dimasukkan ke dalam kantong plastik yang selanjutnya dibawa ke Laboratorium Silvikultur Fakultas Kehutanan Universitas Tanjungpura Pontianak. Penelitian di Laboratorium untuk menentukan jumlah spora, genus dan peresentase kolonisasi FMA pada tanaman jelutung.

Data yang dikumpulkan dalam penelitian berupa jumlah spora, genus FMA dan persentase kolonisasi akar. Sebagai data penunjang dicatat berupa diameter pohon, suhu tanah, $\mathrm{pH}$ tanah suhu udara dan kelembaban sekitar tanaman. Analisa data dilakukan terhadap rata-rata jumlah spora, genus FMA dan peresentase kolonisasi pada perakaran tegakan jelutung. Rumus perhitungan persentase kolonisasi pada akar adalah sebagai berikut.

$$
\text { Peresentase akar }(\%)=\frac{\text { jumlah potong akar terinfeksi }}{\text { jumlah seluruh potongan akar yang diamati }} \times 100 \%
$$

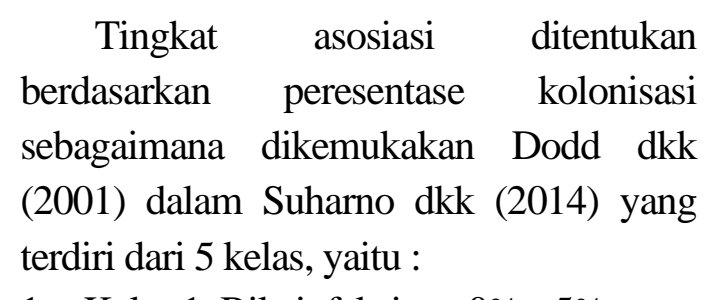

1. Kelas 1, Bila infeksinya 0\%-5\%

(Tidak ada asosiasi FMA)

2. Kelas 2, Bila infeksinya $6 \%-25 \%$ (Tingkat asosiasi FMA sangat rendah)
3. Kelas 3, Bila infeksinya $26 \%-50 \%$ (Tingkat asosiasi FMA rendah)

4. Kelas 4, Bila infeksinya $51 \%-75 \%$ (Tingkat asosiasi FMA sedang)

5. Kelas 5, Bila infeksinya $76 \%-100 \%$ (Tingkat asosiasi FMA tinggi)

Untuk mengetahui ada atau tidaknya hubungan antara ukuran diameter pohon dengan jumlah spora, dilakukan analisis korelasi dengan rumus sebagai berikut. 


$$
r=\frac{n \sum_{i=1}^{n} x_{i} y_{i}-\sum_{i=1}^{n} x_{i} \sum_{i=1}^{n} y_{i}}{\sqrt{n \sum_{i=1}^{n} x_{i}^{2}-\left(\sum_{i=1}^{n} x_{i}\right)^{2}} \sqrt{n \sum_{i=1}^{n} y_{i}^{2}-\left(\sum_{i=1}^{n} y_{i}\right)^{2}}}
$$

\section{Dimana nilai $\mathrm{x}=$ diameter pohon jelutung, dan $\mathrm{y}=$ jumlah spora}

Interpretasi mengenai kekuatan hubungan antara dua variabel digunakan kriteria sebagai berikut :

$>0 \quad$ : Tidak ada korelasi

antara dua variabel

$>0-0,25 \quad$ : Korelasi sangat lemah

$>0,25-0,5 \quad$ : Korelasi cukup

$>0,5-0,75$ : Korelasi kuat

$>0,75-0,99$ : Korelasi sangat kuat

1 : Korelasi sempurna

\section{HASIL DAN PEMBAHASAN}

\section{Hasil Penelitian}

Jumlah spora pada setiap diameter batang

Berdasarkan hasil pengamatan yang dilakukan terhadap tanaman jelutung dengan berbagai ukuran diameter, ditemukan spora FMA pada rhizosfer tanah berpasir. Hasil penelitian pada spora FMA dari 10 sampel dengan berbagai ukuran diameter tanaman jelutung (Dyera spp) yang ditanam pada tapak berpasir daerah Pasir Panjang Kota Singkawang. Hasil perhitungan spora FMA yang diambil dari saringan ukuran $125 \mu \mathrm{m}, 63 \mu \mathrm{m}$ dan $45 \mu \mathrm{m}$, menemukan jumlah yang terbanyak pada saringan $63 \mu \mathrm{m}$. Rata-rata jumlah spora untuk setiap genus FMA dari 10 sampel tanah rizosfer pada setiap ukuran diameter tanaman jelutung (Dyera spp.) berbeda. Jumlah spora FMA terbanyak ditemukan pada rizosfer dengan tanaman berdiameter batang $35 \mathrm{~cm}$ (960 spora/100 g tanah) dan 49,4 cm (1279,67 spora FMA). Jumlah spora sangat sedikit ditemukan pada rizosfer tanaman jelutung berdiameter batang $6, .5 \mathrm{~cm}$ (436 spora FMA).

Tabel 1 menunjukkan rata-rata jumlah

Tabel 1. Rata-rata jumlah spora/100 g tanah berpasir setiap genus FMA pada tanaman jelutung berdasarkan ukuran diameter $(\mathrm{cm})$. (The average number of spores / $100 \mathrm{~g}$ of sandy soil per genus FMA in jelutung plants based on diameter $(\mathrm{cm})$ )

\begin{tabular}{ccccc}
\hline \multirow{2}{*}{ Diameter batang (cm) } & \multicolumn{2}{c}{ Genus Fungi Mikoriza Arbuskula } & \multirow{2}{*}{ Populasi } \\
\cline { 2 - 4 } & Glomus $\mathbf{~ s p}$ & Gigaspora $\mathbf{~ s p}$ & Scutellospora sp & 814,67 \\
$11,5 \mathrm{~cm}$ & 792,67 & 17,33 & 4,67 & 1010,00 \\
$185 \mathrm{~cm}$ & 985,67 & 18,05 & 4,95 & 835,67 \\
$25,5 \mathrm{~cm}$ & 808,33 & 24,00 & 3,33 & 955,67 \\
$31,2 \mathrm{~cm}$ & 928,33 & 19,33 & 8,00 & 960,00 \\
$35 \mathrm{~cm}$ & 937,33 & 16,00 & 6,67 & 947,33 \\
$38 \mathrm{~cm}$ & 926,33 & 16,33 & 4,67 & 896,33 \\
$40 \mathrm{~cm}$ & 846 & 43,33 & 7,00 & 1279,67 \\
$49,4 \mathrm{~cm}$ & 1215,33 & 56,33 & 8,00 & 904,00 \\
$54,5 \mathrm{~cm}$ & 883,67 & 17,00 & 3,33 & 436,00 \\
$61,5 \mathrm{~cm}$ & 419,67 & 12,00 & 4,33 & $\mathbf{8 9 2 , 7 7}$ \\
\hline Rata-rata & $\mathbf{8 7 4 , 3 3}$ & $\mathbf{2 3 , 9 7}$ & $\mathbf{5 , 5 0}$ & \\
\hline
\end{tabular}


Hubungan antara diameter batang dengan jumlah spora dapat diketahui dengan menggunakan analisis korelasi dimana hasilnya dapat dilihat pada Gambar 1. Hasil analisis pada Gambar 1 dengan koefesien determinasi $r^{2}=$ 0,0169 menunjukkan tidak terdapat hubungan yang erat antara ukuran diameter dengan jumlah spora pada rhizosfer tanaman jelutung pada tanah berpasir. Pengaruh diameter tanaman terhadap jumlah spora FMA hanya sebesar $\quad 1,7 \quad \%$ sedangkan $\quad 98,3 \%$ dipengaruhi faktor habitat terutama unsur kimia dan sifat fisik media tanam berupa tanah berpasir.

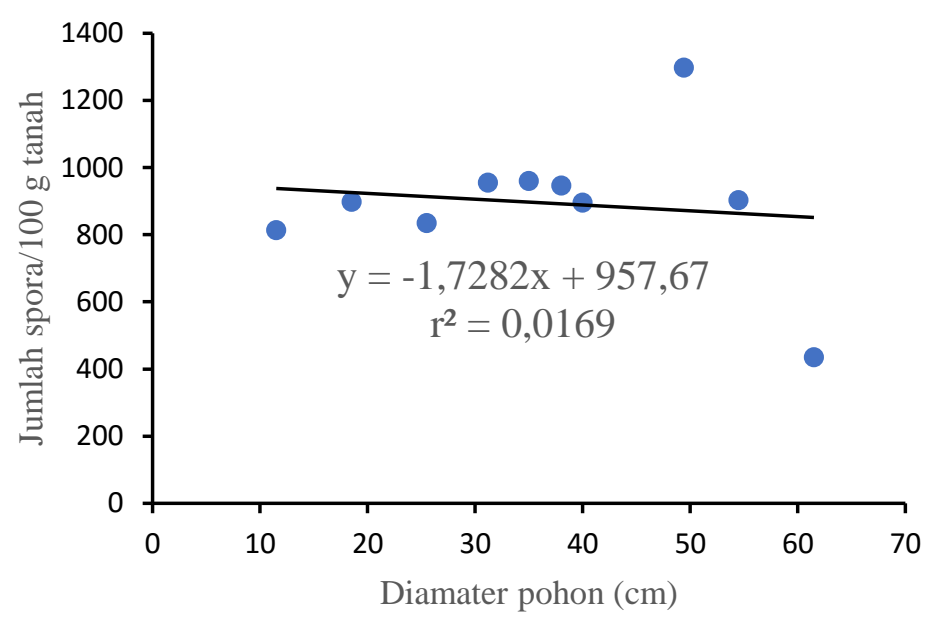

Gambar 1. Grafik hubungan antara jumlah spora dengan ukuran diameter pohon (Graph of relationship between the number of spores and the size of the tree diameter).

Rata-rata jumlah spora setiap genus FMA

Untuk mengetahui genus FMA yang terdapat pada rhizosfer tanaman jelutung dilakukan identifikasi terhadap spora. Identifikasi dilakukan sampai tingkat genus dengan memperhatikan bentuk, warna, ornamen spora, dan lekatan tangkai hifa dari spora FMA. Hasil perhitungan jumlah setiap genus disajikan pada Tabel 1 dengan kharakteristik sporanya dapat dilihat pada Gambar 1. Hasil analisis Genus FMA pada Tabel 1 menunjukkan bahwa Glomus sp lebih banyak dibandingkan dengan Gigaspora sp dan Scutellospora sp. Jumlah genus Glomus sp yang terdapat pada rhizosfer tanaman jelutung (Dyera spp) sebanyak $874,33 / 100$ g tanah $(96,8 \%)$, sementara itu genus Gigaspora sp hanya 23,97/100 g tanah (2,6\%), dan Scutellospora sp hanya 5,50/100 g tanah (0,6\%). Hasil identifikasi karakteristik bentuk, warna, ornamen dan letak tangkai hifa setiap genus dapat dilihat pada Gambar 2. Berdasarkan jumlah spora pada setiap genus dapat diketahui bahwa tanaman jelutung yang ditanam pada habitat tanah berpasir 
lebih banyak berasosiasi dengan Glomus sp. Hasil penelitian ini sama dengan yang dilakukan oleh Fitriani (2019) pada tanaman penage (Calophyllum inophyllum L) di habitat berpasir di Kabupaten Ketapang. Hasil dari identifikasi terhadap genus berdasar warna, bentuk, oranament dan tangkai hifa spora dapat dilihat pada Gambar 2.

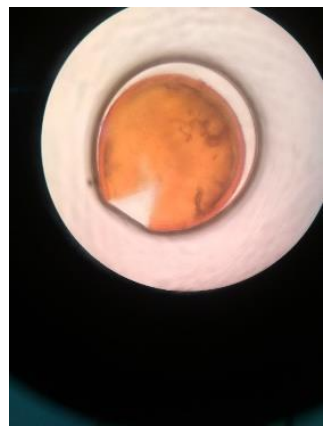

Glomus sp

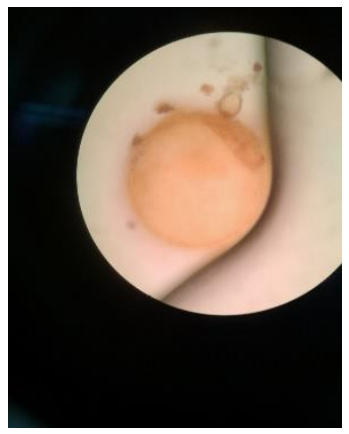

Gigaspora sp

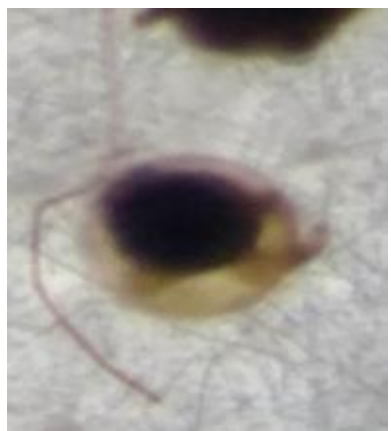

Scuttellospora sp

Gambar 2. Genus FMA yang terdapat pada tanaman jelutung di tanah berpasir (FMA genus was found in jelutung plants in sandy soil)

Hubungan antara jumlah spora pada setiap sampel rizosfer dengan faktor lingkungan perlu diketahui lebih lanjut. Hasil analisis korelasi setiap faktor lingkungan (suhu tanah, suhu udara, $\mathrm{pH}$ dan kelembababn udara) pada Gambar 3 diperoleh koefesien korelasi (Nilai $\mathrm{r}^{2}$ ) yang sangat rendah atau tidak berkorelasi. Hasil analisis korelasi pada Gambar 3 menunjukkan bahwa kisaran suhu tanah, $\mathrm{pH}$, suhu udara dan kelambaban merupakan faktor lingkungan yang sangat sesuai untuk perkembangan FMA. 

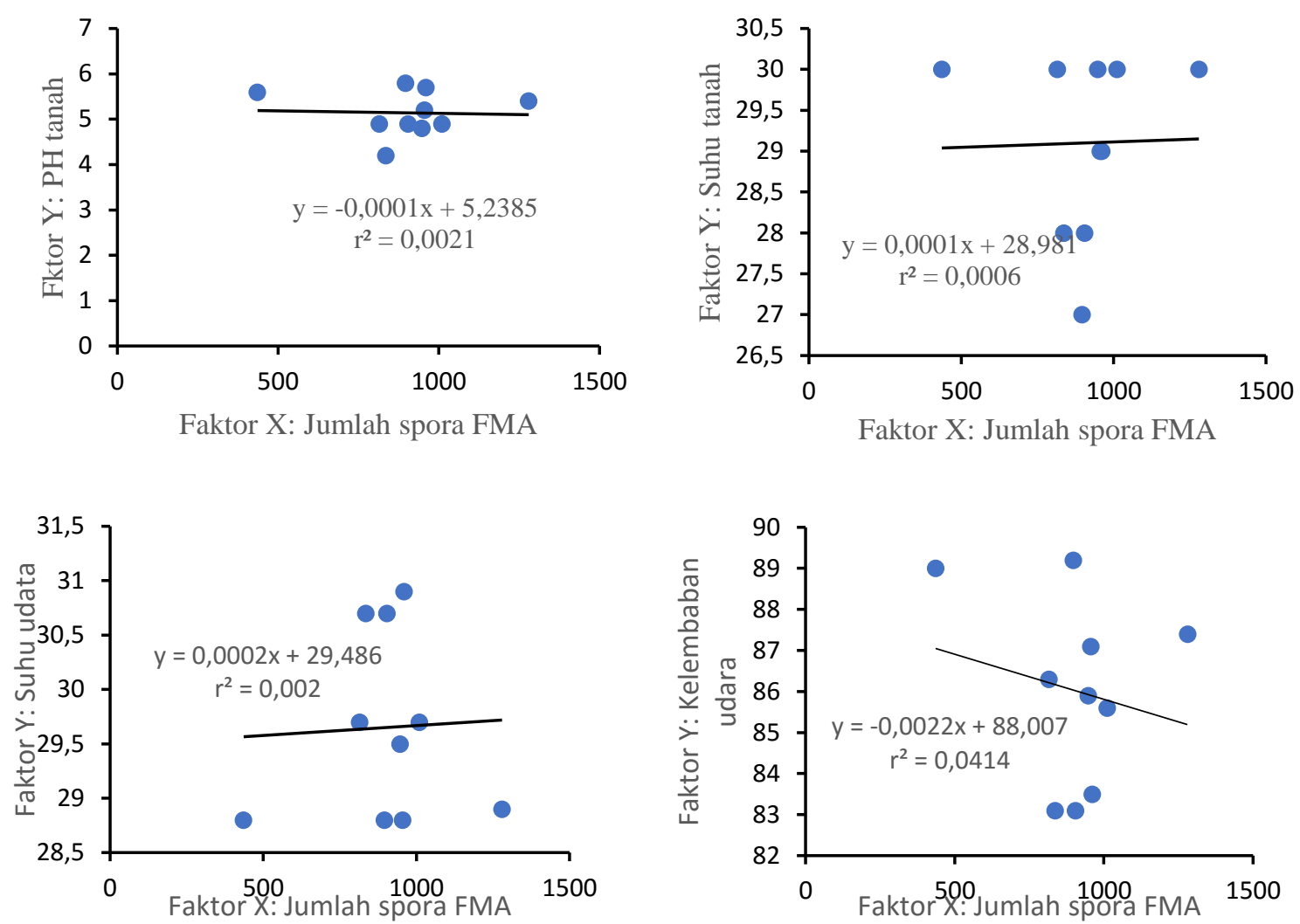

Gambar 3. Hubungan faktor lingkungan dengan jumlah spora/100 g tanah (The relationship of environmental factors with the amount of spores / $100 \mathrm{~g}$ of soil).

Persentase akar terinfeksi FMA

Hasil perhitungan rata-rata akar terinfeksi oleh fungi mikoriza arbuskula (FMA) pada tanaman jelutug (Dyera spp) dengan berbagai ukuran diameter dapat dilihat pada Tabel 2. Hasil pengamatan infeksi FMA pada akar dalam Tabel 2, menunjukan bahwa tanaman jelutung yang ditanam pada habitat berpasir berasosiasi dengan Fungi Mikoriza arbusrkula (FMA). Berdasarkan klasifikasi tingkat asosiasi sebagaimana dikemukakan dalam The Institute of Mycorrizal Research and
Development, USDA Forest Service, Athena, Georgia, ternyata tanaman jelutung tersebut termasuk tingkat asosiasi tinggi. Hasil perhitungan persentase infeksi yang terjadi pada akar tanaman jelutung tersebut berkisar antara 8,7 - $100 \%$. Sebagaimana dikemukan Suharno et. al, (2014) bahwa persentase infeksi akar lebih dari 75\% dinyatakan tingkat asosaisi FMA tinggi. Berdasarkan hasil pengamatan, bahwa pada akar tanaman jelutung hanya ditemukan vesikula sebagaimana terlihat pada Gambar 3. 
Tabel 2. Rata-rata persentase infeksi akar pada berbagai ukuran diameter tanaman jelutung (Dyera spp) (The average percentage of root infections in various diameter sizes of jelutung plants (Dyera spp))

\begin{tabular}{cccccc}
\hline $\begin{array}{c}\text { Diameter Batang } \\
(\mathrm{cm})\end{array}$ & $\begin{array}{c}\text { Jumlah } \\
\text { Potongan Akar }\end{array}$ & $\begin{array}{c}\text { Jumlah Akar } \\
\text { Terinfeksi }\end{array}$ & $\begin{array}{c}\text { \% Infeksi } \\
\text { Akar }\end{array}$ & $\begin{array}{c}\text { Kelas } \\
\text { tingkat } \\
\text { asosiasi }\end{array}$ & $\begin{array}{c}\text { Keterangan } \\
\text { tingkat asosiasi }\end{array}$ \\
\hline $11,5 \mathrm{~cm}$ & 10 & 10 & 100 & kelas 5 & Tinggi \\
$18,5 \mathrm{~cm}$ & 10 & 10 & 100 & kelas 5 & Tinggi \\
$25,5 \mathrm{~cm}$ & 10 & 10 & 100 & kelas 5 & Tinggi \\
$31,2 \mathrm{~cm}$ & 8,7 & 10 & 87 & kelas 5 & Tinggi \\
$35 \mathrm{~cm}$ & 8,7 & 10 & 87 & kelas 5 & Tinggi \\
$38 \mathrm{~cm}$ & 10 & 10 & 100 & kelas 5 & Tinggi \\
$40 \mathrm{~cm}$ & 10 & 10 & 100 & kelas 5 & Tinggi \\
$49,4 \mathrm{~cm}$ & 10 & 10 & 100 & kelas 5 & Tinggi \\
$54,5 \mathrm{~cm}$ & 10 & 10 & 100 & kelas 5 & Tinggi \\
$61,5 \mathrm{~cm}$ & 9,7 & 10 & 97 & kelas 5 & Tinggi \\
\hline Rata- rata & 97,1 & 100 & 97,1 & kelas 5 & Tinggi \\
\hline
\end{tabular}

Hasil pengamatan infeksi akar sebagaimana terlihat pada Gambar 3, membuktikan telah terjadi asosiasi FMA, dimana hifa menginfeksi jaringan korteks akar tanaman jelutung. Setelah melalui proses perendaman akar, terlihat vesikula, jaringan akar dan hifa internal FMA yang menyebar luas dalam korteks akar pada tanaman jelutung tersebut.

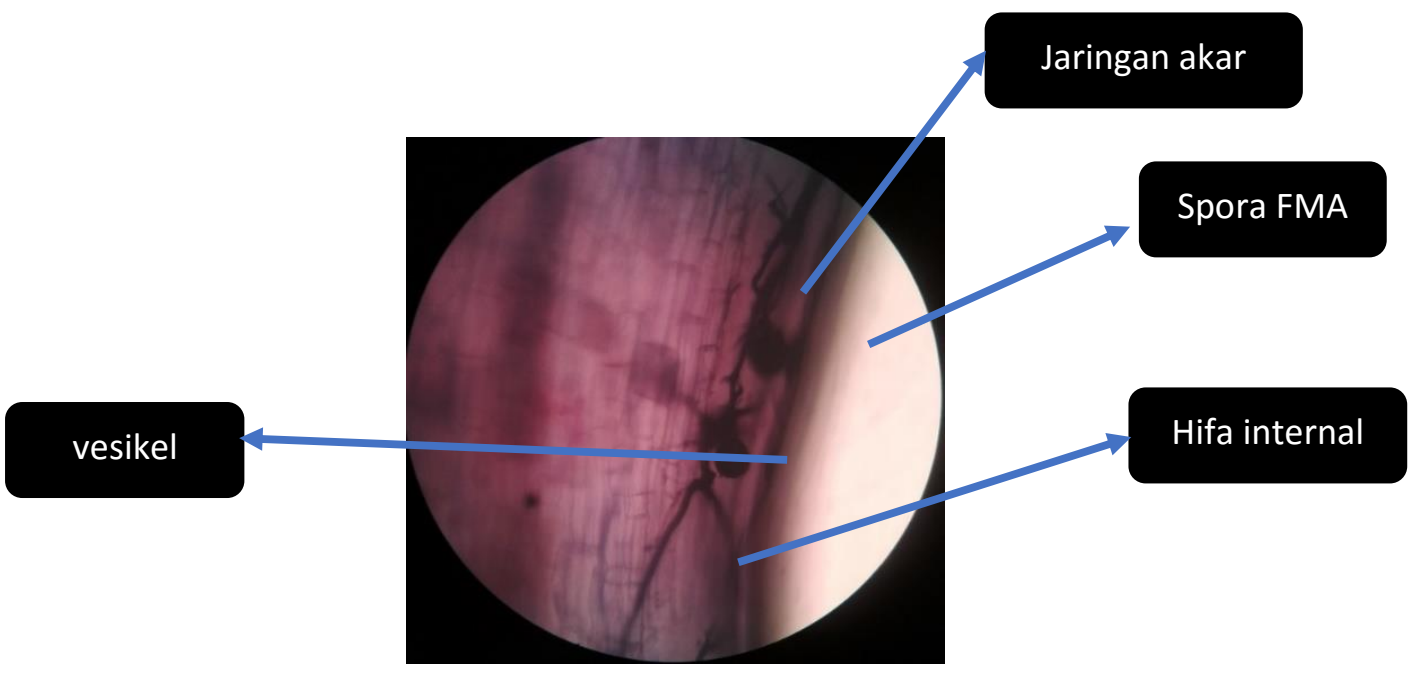

Gambar 3. Infeksi FMA pada akar tanaman jelutung (Dyera sp)( FMA infection in the roots of jelutung (Dyera spp))

\section{Pembahasan}

Berdasarkan hasil pengamatan terhadap spora yang ditemukan pada rhizosfer dan infeksi akar sebagaimana dikemukakan diatas, dapat disimpulkan bahwa tanaman jelutung (Dyera spp) di habitat tanah berpasir berasoasiasi dengan FMA. Hasil pengamatan jumlah spora dan infeksi akar menunjukkan bahwa tanaman jelutung tersebut tumbuh dengan subur 
karena berasoasiasi dengan FMA, meskipun pada tanah berpasir yang merupakan bukan habitat aslinya. Hasil penelitian Turjaman et. al (2007) bahwa tanaman jelutung pada habitat aslinya berasosaiasi dengan FMA, sementara penelitian yang dilakukan oleh Fitriani (2019) bahwa pada tanah berpasir terdapat sejumlah spora dan infeksi FMA pada akar permudaan tanaman panage (Callophyllum sp). Kedua hasil penelitian tersebut membuktikan bahwa jelutung (Dyera spp) merupakan salah satu jenis tanaman yang hidupnya membutuhkan asosiasi dengan FMA, meskipun ditanam pada tanah berpasir.

Asoasiasi FMA dengan tanaman termasuk jelutung dipengaruhi oleh faktor lingkungan terutama suhu tanah dan $\mathrm{pH}$ tanah. Hasil pengamatan terhadap suhu dan $\mathrm{pH}$ tanah di lokasi menunjukkan bahwa factor lingkungan berupa suhu tanah $27-30^{\circ} \mathrm{C}$ dan $\mathrm{pH}$ tanah antara 4.,5 5,89 merupakan yang terbaik untuk perkembangan FMA pada tanaman jelutung di tanah berpasir Pasir Panjang Kota Singkawang Hasil analisis korelasi menunjukkan bahwa faktor lingkungan tersebut tidak berpangaruh terhadap perkembangan FMA. Hasil penelitian Padri (et. al. 2015) menemukan bahwa FMA pada suhu tanah $30-33{ }^{\circ} \mathrm{C}$.

Menurut Petrus (et al, 2013) suhu tanah yang terbaik untuk perkembangan mikoriza adalah $\pm 30{ }^{\circ} \mathrm{C}$ atau antara $28{ }^{\circ} \mathrm{C}$ $-32{ }^{0} \mathrm{C}$ (Muin, 2009). Sementara itu pada $\mathrm{pH}$ 4,0 - 6,0 merupakan terbaik untuk perkembangan FMA (Ristiyanti et al. 2014).
Hasil pengamatan suhu udara berkisar antara $28,8-30,7^{\circ} \mathrm{C}$ dan kelembaban 83,5 89,2 \% merupakan kondisi lingkungan yang tidak berpengaruh langsung terhadap perkembangan FMA pada tanah berpasir. Suhu udara dan kelembaban udara berpengaruh terhadap proses pertumbuhan dan perkembangan jelutung melalui proses fotosintesis. Tanjungsari et. al (2016) menyebutkan bahwa suhu tempat tumbuh jelutung berkisar $23^{\circ} \mathrm{C}-28^{\circ} \mathrm{C}$ dengan kelembaban berkisar $77 \%$ - $89 \%$. Pengaruh tidak langsung terhadap perkembangan spora, berupa hasil fotosintesis yang disuplai ke fungi mikoriza. Suhu dan kelembaban yang sesuai dengan pertumbuhan tanaman, akan menghasilkan karbohidrat yang cukup untuk disuplai ke fungi mikoriza, sehingga proses ineraksi terjalin dengan sempurna. Menurut Nasution $d k k$. (2013) bahwa FMA membentuk interaksi yang kompleks pada tanaman sekaligus merupakan suatu bentuk hubungan simbiosis mutualistik, dimana tanaman mendapatkan unsur hara dan mineral yang cukup, sedangkan FMA mendapatkan karbohidrat yang dihasilkan dari proses fotosintesis tanaman. Tanaman jelutung berada di tempat yang terbuka, mendapatkan sinar matahari penuh, suhu dan kelembabab udara, sehingga proses fotosintesis bisa terjadi secara maksimal. Muin (2009) mengemukakan bahwa suplai karbon mempengaruhi proses pertumbuhan dan fungsi mikoriza pada tanaman melalui proses fotosintesis. Hasil pengamatan infeksi FMA pada akar tanaman jelutung terlihat adanya vesikular yang berfungsi sebagai pertukaran 
metabolit antara fungi dan tanaman. Vesikular adalah organ yang berbentuk oval seperti kantong yang disebabkan adanya penggelembungan pada bagian ujung hifa. Menurut Delvian (2005) bahwa vesikular adalah bagian struktur FMA yang sangat penting dalam proses infeksi, karena struktur tersebut memiliki fungsi yang saling berkaitan antara pertukaran metabolit dan penyimpanan karbohidrat.

\section{KESIMPULAN}

Hasil penelitian yang telah dilakukan dapat disimpulkan bahwa tanaman jelutung (Dyera spp) yang tumbuh pada habitat berpasir di daerah Pasir Panjang Kota Singkawang berasosiasi dengan fungi mikoriza arbuskula (FMA). Asosaiasi ini yang terjadi pada tanaman jelutung tersebut dapat dilihat pada:

1. Jumlah spora yang terdapat pada rhizosfer tanaman jelutung di habitat tanah berpasir cukup banyak (4361279/100 g tanah).

2. Uji korelasi dengan determinasi $\mathbf{r}^{2}=$ 0,0169 menunjukkan tidak ada hubungan jumlah spora FMA yang terdapat pada rhizosfer dengan ukuran diameter batang tanaman jelutung di tanah berpasir.

3. Genus Glomus sp yang terdapat pada rhizosfer tanaman jelutung (Dyera spp.) sebanyak 874,33/100 g tanah (96,8\%), sementara itu genus Gigaspora sp hanya 23,97/100 g tanah $(2,6 \%)$, dan Scutellospora sp hanya $5,50 / 100 \mathrm{~g}$ tanah $(0,6 \%)$.

4. Persentase infeksi yang terjadi pada akar tanaman jelutung berkisar antara $87-100 \%$ berada kelas 5, menunjukkan bahwa asosiasi FMA dengan tanaman jelutung sangat tinggi.

\section{Saran}

1. Berdasarkan hasil penelitian tersebut bahwa untuk penanaman jelutung dapat dilakukan di luar habitatnya jika bersimbiosis dengan FMA.

2. Perlu dilakukan penelitian uji efektivitas terhadap ketiga genus FMA pada tanaman jelutung agar ditentukan genus yang terbaik untuk diinokulasikan pada bibit jelutung.

3. Perlu dilakukan penelitian hubungan jumlah spora dan data di lapangan disekitar tanaman jelutung.

\section{DAFTAR PUSTAKA}

Delvian. 2005. Respon Pertumbuhan dan Perkembangan Cendawan Mikoriza Arbuskula dan Tanaman terhadap Salinitas Tanah.Medan: USU Repository.

Fitriani, A. 2019. Asosiasi Fungi Mikoriza Arbuskula (Fma) Pada Berbagai Tinggi Semai Permudaan Alam Nyamplung ( Calophyllum Inophyllum L) Di Kabupaten Ketapang. Jurnal Hutan Lestari.7(2): 706-715

Padri, M.H. Burhanudin. Herawatiningsih, R. 2015. Keberadaan Fungi Mikoriz Arbuskula Pada Jabon Putih Dilahan Gambut. JurnalHutan Lestar 3(3): 401-410.

Muin, A 2009. Teknologi Penanaman Ramin (Gonystylus bancamus (Miq.) Kurz) pada Areal Bekas Tambang. Pontianak: Untan Press.

Nasution TK, Rosmayati, Husni Y. 2013. Respon pertumbuhan dan produksi keledai (Glycine max (1.) Merrill) yang diberi fungi mikoriza 
arbuskula (fma) pada tanah salin. Jurnal online Agroekteknologi 2(1): 421-427.

Nurhatika, S., N. Kadek, M. D. Cahyani, Anton Muhibuddin, 2014. Eksplorasi mikoriza versikular arbusrkula (FMA) indigebous pada Tanah Aluvial di Kabupaten Pemekasan Madura. Jurnal Sains dan Seni Poits. 3(1): 22-25.

Petrus, Burhanuddin, dan Wulandari RS. 2013. Asosiasi Cendawan mikoriza Arbuskula (CMA) Pada Ketapang (Terminalia catappa). Jurnal Hutan Lestari 1(3): 258-267.

Ristiyanti, Yusran, Rahmawati. 2014. Pengaruh Berberapa Spesies Fungi Mikoriza Arbuskula pada Media Tanah dengann $\mathrm{pH}$ berbeda terhadap Pertumbuhan Semau Kemiri (Aleurites moluccana (L). Willd.). Jurnal Warta Rimba 2(2): 117-124.

Sitepu, I. R, Mansur, I, Atunnisa, R. 2010. Pemanfaatan Bakteri Rhizoplane dan Fungi Mikoriza Arbuskula (FMA) untuk Meningkatkan Pertumbuhan Semai Jelutung (Dyera polyphylla Miq. Steenis.). Jurnal Silvikultur Tropika 01(01): 18-23.

Sofiyuddin M, Janudianto, Perdana A. 2012. Potensi Pengembangan dan Pemasaran Jelutung di Tanjung
Jabung Barat. Brief No 23. Bogor, Indonesia. World Agroforestri Centre - ICRAF, SEA Regional Office. 4p. Jurnal Media Konservasi 21(1): 1-8.

Suharno, Sancayaningsih, R.P, Soetarto, E.S, Kasiamdari, R.S. 2014. Keberadaan Fungi Mikoriza Arbuskula Di Kawasan Tailing Tambang Emas Timika Sebagai Upaya Rehabilitas Lahan Ramah Lingkungan. Jurnal Manusia dan Lingkungan. 21(3): 295-303.

Tanjungsari, R. J, Zuhud, E. A. M, Siregar, I. Z. 2016. Pendugaan Potensi Populasi Dan Ekologi Jelutung (Dyera Costulata (Miq.) Hook. F) Di Harapan Rain Forest (Hrf-Pt Reki) Jambi. Media Konservasi. 21(1): 1-8.

Turjaman, M, Saito H, Santoso E, Susanto A, Sampang G, Limin SH, Shibuya M, Takahashi K, Tamai Y, Osaki M, dan Tawaraya K. 2007. Effect of Ectomycorrhizal Fungi Inoculated on Shoreabalangeran Under Field Condition in Peat Swamp Forest. Dalam Proceeding International Symposiumand Workshop on Tropical Peatland. Carbon-Climate-Human interaction -Carbon Pools, Fire, Mitigation, Restoration and Wise Use. Yogyakarta: Indonesia. 